\section{BRAZIULIAN JOURNAL \\ OF MEDICAL AND BIOLOGICAL RESEARCH}

www.bjournal.com.br
ISSN 1414-431X

Volume 45 (12) 1102-1340 December 2012

\section{BIOMIDICAL SCIENCES}

AND

CLINICAL INVESTIGATION

Braz J Med Biol Res, December 2012, Volume 45(12) 1135-1140

doi: 10.1590/S0100-879X2012007500146

Effect of ATP and 2-oxoglutarate on the in vitro interaction between the NifA GAF domain and the GlnB protein of Azospirillum

brasilense

P. Sotomaior, L.M. Araújo, C.Y. Nishikawa, L.F. Huergo, R.A. Monteiro, F.O. Pedrosa, L.S. Chubatsu and E.M. Souza

The Brazilian Journal of Medical and Biological Research is partially financed by

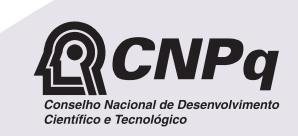

Ministério
da Ciência e Tecnologia

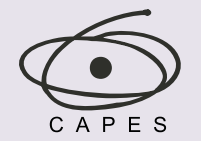

Ministério da Educação
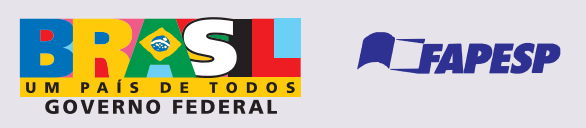

Institutional Sponsors
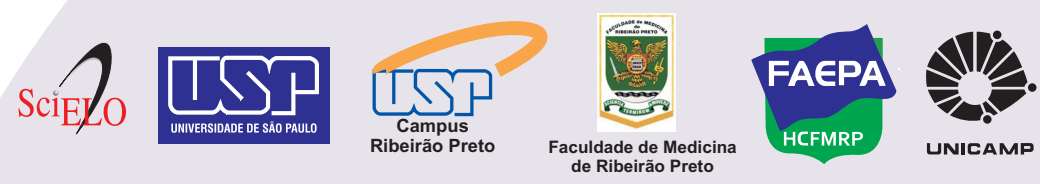

Ф SHIMADZU

UNICAMP
DTHPSP

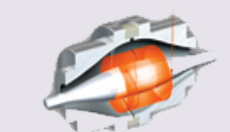

CDID Associaçäo Explore High - Performance MS Orbitrap Technology In Proteomics \& Metabolomics $\underset{\text { analitica }}{\text { analiticaweb.com.br }}$ Thermo 


\title{
Effect of ATP and 2-oxoglutarate on the in vitro interaction between the NifA GAF domain and the GlnB protein of Azospirillum brasilense
}

\author{
P. Sotomaior*, L.M. Araújo*, C.Y. Nishikawa, L.F. Huergo, R.A. Monteiro, \\ F.O. Pedrosa, L.S. Chubatsu and E.M. Souza \\ Departamento de Bioquímica e Biologia Molecular, Universidade Federal do Paraná, Curitiba, PR, Brasil
}

\begin{abstract}
Azospirillum brasilense is a diazotroph that associates with important agricultural crops and thus has potential to be a nitrogen biofertilizer. The $A$. brasilense transcription regulator NifA, which seems to be constitutively expressed, activates the transcription of nitrogen fixation genes. It has been suggested that the nitrogen status-signaling protein GInB regulates NifA activity by direct interaction with the NifA N-terminal GAF domain, preventing the inhibitory effect of this domain under conditions of nitrogen fixation. In the present study, we show that an N-terminal truncated form of NifA no longer required GInB for activity and lost regulation by ammonium. On the other hand, in trans co-expression of the $\mathrm{N}$-terminal GAF domain inhibited the $\mathrm{N}$-truncated protein in response to fixed nitrogen levels. We also used pull-down assays to show in vitro interaction between the purified $\mathrm{N}$ terminal GAF domain of NifA and the GInB protein. The results showed that $A$. brasilense GInB interacts directly with the NifA $\mathrm{N}$-terminal domain and this interaction is dependent on the presence of ATP and 2-oxoglutarate.
\end{abstract}

Key words: Azospirillum brasilense; NifA protein; GInB protein; GAF domain; Nitrogen fixation

\section{Introduction}

Azospirillum brasilense is a microaerophilic diazotrophic a-proteobacterium associated with several plants of agricultural interest, such as maize, rice, sorghum, wheat, and sugar cane (1). This bacterium reduces $\mathrm{N}_{2}$ to $\mathrm{NH}_{3}$ by the nitrogenase enzyme complex, which is encoded by the nifHDK genes. Nitrogen fixation requires large amounts of metabolic energy, which suggests why this process is highly regulated at the level of both nif gene expression and nitrogenase activity.

The two major environmental factors that regulate nitrogen fixation in most diazotrophs are oxygen and ammonium (2). In Proteobacteria, control of the activity of the nif gene transcription activator, the NifA protein, by these factors is the key step in the regulation of nitrogenase expression. The NifA protein consists of three typical structural domains (2). The N-terminal GAF domain is the most variable among NifA proteins and has a regulatory function. The $\mathrm{N}$-terminal and central domains are separated by a glutamine-rich linker named $\mathrm{QL}$. The central AAA+ domain is the catalytic domain and contains ATPase and $\sigma^{54}$-binding sites. The C-terminal domain contains a conserved helix-turn-helix motif, which is involved in DNA binding. In A. brasilense and other diazotrophs, such as Bradyrhizobium japonicum and Herbaspirillum seropedicae, the two latter domains are connected by an interdomain linker region $(2,3)$. Two cysteines present in this region, together with two cysteines from the central domain, may be involved in oxygen sensitivity of the NifA proteins of these organisms $(2,4)$.

In $A$. brasilense and $H$. seropedicae the $\mathrm{N}$-terminal GAF domain is not essential for NifA activity $(4,5)$, although it is required for inhibition of NifA activity in the presence of fixed nitrogen. It has been proposed that this control involves direct interaction between the NifA GAF domain and the GlnB protein in $A$. brasilense $(6,7)$. This model suggests that GInB binds to NifA under low levels of fixed nitrogen and relieves the inhibition by the GAF domain

Correspondence: E.M. Souza, Departamento de Bioquímica e Biologia Molecular, Universidade Federal do Paraná, Caixa Postal 19046, 81531-980 Curitiba, PR, Brasil. Fax: +55-41-3266-2042. E-mail: souzaem@ufpr.br

*These authors contributed equally to this study.

Received May 21, 2012. Accepted August 27, 2012. Available online September 21, 2012. Published December 17, 2012. 
of the central AAA+ domain (5-8). Recent studies have shown that amino acid residues $66-88$ and $165-176$ in the NifA GAF domain are responsible for the interaction with $G \ln B(8)$. $G \ln B$ is a homotrimeric protein of the $P_{\|}$ family that can sense the cellular nitrogen, carbon and energy levels and relay these signals to a variety of target proteins by means of protein-protein interactions. These protein interactions are modulated by the uridylylation status of GlnB, which, in turn, reflects the availability of the nitrogen-signaling molecule glutamine. Furthermore, GlnB-targeting interactions are influenced by the allosteric binding of 2-oxoglutarate, ATP and ADP to GInB. The levels of 2-oxoglutarate reflect the nitrogen/carbon availability while the competitive binding of ATP and ADP to GInB reflects the energy level (reviewed in Ref. 9). Two different $P_{\|}$proteins, namely $G \ln B$ and $G \ln Z$, have been identified in A. brasilense (10); however, only GInB is able to activate NifA under nitrogen limitation (6).

In the present study, we analyzed the in trans regulatory function of the $\mathrm{N}$-terminal GAF domain of $A$. brasilense NifA using Escherichia coli strains with a chromosomal nifH'-lacZ fusion and expressing an $\mathrm{N}$-truncated variant of NifA. We also demonstrate that the GInB protein binds the $\mathrm{N}$-terminal domain of NifA in vitro in the presence of ATP and 2-oxoglutarate, and discuss the biological relevance of this result.

\section{Material and Methods}

\section{Reagents}

All chemicals were of analytical or molecular biology grade and were purchased from Merck (Germany), Sigma (USA), J.T. Baker (The Netherlands), or Invitrogen (USA). Restriction enzymes were from Fermentas (Lithuania) or Invitrogen. Oligonucleotides were from Invitrogen. HiTrap Chelating and HiTrap Heparin chromatographic columns were products of GE Healthcare (Sweden). MagneHis ${ }^{\mathrm{TM}}$ Ni-particles were from Promega (USA). SYPRO ${ }^{\circledR}$ Ruby was from Invitrogen.

\section{Bacterial strains and plasmids}

The bacterial strains and plasmids used are listed in Table 1.

\section{Plasmid construction}

The DNA fragment encoding the $\mathrm{N}$-truncated NifA protein was excised from the plasmid pCNpETCCT (11) as an Xbal/ HindIII fragment and cloned into pDK5 (12), yielding the plasmid pCNK5CCT. The sequence encoding the $\mathrm{N}$-terminal GAF domain of the NiFA protein was amplified using the primers NifA5'NT (5'-GGTGTCGCATATGCCGGTG-3') and NifA3'Cent (5'-CATGAAGCTTTACTCCTCGGCC-3'), which introduced $\mathrm{Ndel}$ and HindIII restriction sites, respectively

Table 1. Bacterial strains and plasmids used.

\begin{tabular}{|c|c|c|}
\hline & Genotype/characteristics & Reference/source \\
\hline \multicolumn{3}{|l|}{ Escherichia coli } \\
\hline BL21(גDE3)pLysS & hsdS gal ( $\lambda$ clts 857 ind1 Sam7 nin5 lacUV5-T7 gene 1) & Novagen \\
\hline $\mathrm{DH} 10 \mathrm{~B}$ & SmR, F'[proAB + lacZuM15] & Invitrogen \\
\hline YMC10(nifH'-lacZ) & $\Delta l a c U 169$ endA1 thi-1 hsdR17 supE44 hutCK $\left[K^{R}{ }^{R} \Phi(\right.$ nifH'-lacZ)] & 15 \\
\hline RB9060(nifH'-lacZ) & $\begin{array}{l}\Delta l a c U 169 \text { endA1 thi-1 hsdR17 supE44 hutCK } \Delta g \ln B 2306 \\
{\left[K^{R} m_{-} \Phi(\text { nifH'-lacZ)] }\right.}\end{array}$ & 15 \\
\hline WCH30(nifH'-lacZ) & 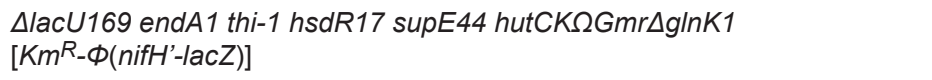 & 15 \\
\hline UNF3435(nifH'-lacZ) & $\begin{array}{l}\Delta l a c U 169 \text { endA1 thi-1 hsdR17 supE44 hutCK } \Delta g \ln B 2306 \Omega G m r \Delta g I n K 1 \\
{\left[K^{R} m_{-} \Phi(\text { nifH'-lacZ)] }\right.}\end{array}$ & 15 \\
\hline \multicolumn{3}{|c|}{ 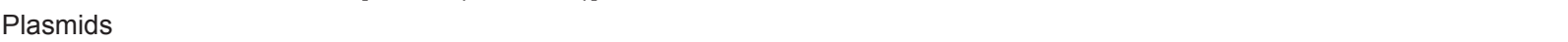 } \\
\hline pET28a & Expression vector/T7 promoter, $\mathrm{Km}^{\mathrm{R}}$ & Novagen \\
\hline pT7-7 & Expression vector/T7 promoter, $\mathrm{Amp}^{\mathrm{R}}$ & New England Biolabs \\
\hline pDK5 & Expression vector/tac promoter, $A m p^{R}$ & 12 \\
\hline $\mathrm{pDK} 7$ & Expression vector/tac promoter, $\mathrm{Cm}^{\mathrm{R}}$ & 12 \\
\hline pCR2.1 & Cloning vector, $\mathrm{Km}^{\mathrm{R}}, \mathrm{Amp}^{\mathrm{R}}$ & Invitrogen \\
\hline pLMA4 & A. brasilense $g \ln B$ in $\mathrm{pT7}-7, \mathrm{Amp}^{\mathrm{R}}$ & 6 \\
\hline pLANTpET & $\begin{array}{l}\text { His-tagged } A \text {. brasilense nifA N-terminal region cloned as Ndel/HindIII } \\
\text { fragment in pET28a }\end{array}$ & Present study \\
\hline pCNK5CCT & $\begin{array}{l}\text { His-tagged } A \text {. brasilense } \mathrm{N} \text {-truncated nifA cloned as HindlII/Xbal fragment } \\
\text { in } \mathrm{pDK} 5, \mathrm{Amp}^{\mathrm{R}}\end{array}$ & Present study \\
\hline pCNK7NT & $\begin{array}{l}\text { His-tagged } A \text {. brasilense nifA N-terminal region cloned as HindIII/Xbal } \\
\text { fragment in } \mathrm{pDK} 7, \mathrm{Cm}^{\mathrm{R}}\end{array}$ & Present study \\
\hline
\end{tabular}


(underlined), and cloned into the pCR2.1 cloning vector (Invitrogen), yielding the plasmid pLANTTA. The amplified fragment was sequenced to confirm gene integrity. The Ndel/ HindIII fragment obtained from pLANTTA was then cloned into pET28a to yield the plasmid pLANTpET. To obtain the plasmid $\mathrm{pCNK} 7 \mathrm{NT}$, the $\mathrm{Xbal} / \mathrm{Hind}$ III fragment excised from pLANTpET was cloned into pDK7 (12).

\section{Protein purification procedure}

To purify the NifA N-terminal GAF domain, the E. coli strain BL21( $\mathrm{DDE} 3) p L y s S$ carrying plasmid pLANTpET was induced with $0.5 \mathrm{mM} \mathrm{IPTG}$ at $18^{\circ} \mathrm{C}$ overnight. After harvesting, cells were resuspended in buffer $S(50 \mathrm{mM}$ Tris- $\mathrm{HCl}, \mathrm{pH} 8.0,500 \mathrm{mM} \mathrm{NaCl}, 1 \mathrm{mM}$ DTT, 10\% glycerol) and lysed by sonication. The crude extract was clarified by centrifugation at $12,000 \mathrm{~g}$ for $30 \mathrm{~min}$. The soluble fraction containing the $\mathrm{N}$-terminal domain was loaded onto a Hitrap-chelating- $\mathrm{Ni}^{2+}$ column pre-equilibrated in buffer $\mathrm{S}$. Two washing steps were performed using 15 column volumes each of buffer W1 (50 mM Tris- $\mathrm{HCl}, \mathrm{pH} 6.3,500 \mathrm{mM} \mathrm{NaCl}$, $10 \mathrm{mM}$ imidazole) and buffer W2 (50 mM Tris- $\mathrm{HCl}, \mathrm{pH}$ $6.3,500 \mathrm{mM} \mathrm{NaCl}, 40 \mathrm{mM}$ imidazole). The proteins were eluted by a stepwise increase of imidazole $(50,100,300$, 500 , and $1000 \mathrm{mM}$ ) in buffer (50 mM Tris- HCl, $\mathrm{pH} 8.0,100$ $\mathrm{mM} \mathrm{KCl}, 10 \%$ glycerol), using five column volumes of each concentration. The $A$. brasilense $\mathrm{GlnB}$ and $\mathrm{G} \operatorname{lnZ}$ proteins were purified by the method of Araújo et al. (13), except that a heat treatment of the crude extract at $80^{\circ} \mathrm{C}$ for 10 min was included (14).

\section{Protein analysis}

Protein concentration was determined by the Bradford method using bovine serum albumin as a standard. Protein expression and purification was analyzed by $12.5 \%$ SDSPAGE and proteins were stained with Coomassie blue R-250 or SyPro Ruby.

\section{Pull-down assays}

AMagneHis ${ }^{\mathrm{TM}} \mathrm{Ni}^{2+}$-particle suspension was equilibrated in binding buffer containing $50 \mathrm{mM}$ Tris- $\mathrm{HCl}, 100 \mathrm{mM} \mathrm{NaCl}$, $5 \mathrm{mM} \mathrm{MgCl}_{2}, 0.05 \%$ Tween-20, and $20 \mathrm{mM}$ imidazole, $\mathrm{pH}$ 8.0. The NifA N-terminal domain, at a concentration of 0.25 $\mu \mathrm{M}$, was immobilized by pre-incubation in a total volume of $500 \mu \mathrm{L}$ containing $25 \mu \mathrm{L}$ of the magnetic bead suspension. After $5 \mathrm{~min}$, the beads were washed in the above buffer and A. brasilense $\mathrm{GlnB}$ was added to a final concentration of $0.8 \mu \mathrm{M}$ in a volume of $500 \mu \mathrm{L}$, in the presence or absence of the ATP or ADP effectors (3.5 mM) and 2-oxoglutarate (2 $\mathrm{mM})$. After an additional $15 \mathrm{~min}$ of incubation, the beads were washed with binding buffer in the presence or absence of the effectors, the buffer was removed, and elution performed with elution buffer (binding buffer with 1 $\mathrm{M}$ imidazole). Aliquots of each sample were analyzed by $12.5 \%$ SDS-polyacrylamide gel electrophoresis. The gels were stained with the fluorescent dye SyPro Ruby, visual- ized using a 302 UV transilluminator and recorded with a cooled CCD camera (Biochemi, UVP, USA). The LabWorks Image Acquisition and Analysis software (UVP) version 4.0.0.8 was used for analysis of the gel images.

\section{Transcription activation of a nifH'-lacZ fusion}

E. colistrains containing a Klebsiella pneumoniae nifH'lacZ chromosomal fusion (15) and carrying plasmids expressing $A$. brasilense $\mathrm{N}$-truncated NifA and NifAN-terminal GAF domain were grown overnight at $37^{\circ} \mathrm{C}$ in nitrogen-free Davis and Mingioli (NFDM) medium (16) containing 5\% LB medium, $5 \mathrm{mg} / \mathrm{L} \mathrm{CaCl} 2,0.1 \mathrm{~g} / \mathrm{L} \mathrm{NaCl}, 5 \mu \mathrm{g} / \mathrm{mL}$ thiamine, $100 \mu \mathrm{g} / \mathrm{L}$ glutamine and antibiotics as required. The cultures were diluted to an absorbance at $600 \mathrm{~nm}$ of $0.1 \mathrm{in} \mathrm{NFDM}$ medium plus $5 \mu \mathrm{g} / \mathrm{L}$ thiamine, $5 \mathrm{mg} / \mathrm{L} \mathrm{CaCl}_{2}, 0.1 \mathrm{~g} / \mathrm{L} \mathrm{NaCl}$, $100 \mu \mathrm{g} / \mathrm{L}$ glutamine, $100 \mu \mathrm{g} / \mathrm{L}$ serine, $0.5 \mathrm{mM}$ IPTG and antibiotics. The cell suspensions were incubated for 16 $h$ at $30^{\circ} \mathrm{C}$ in the presence or absence of $20 \mathrm{mM} \mathrm{NH}_{4} \mathrm{Cl}$, under air or $\mathrm{N}_{2}$, and assayed for $\beta$-galactosidase activity. The relative levels of $\mathrm{N}$-truncated NifA and NifA N-terminal domain proteins were determined by immunoblots.

$\beta$-galactosidase activity was determined using o-nitrophenyl- $\beta$-galactoside as described by Miller (17) and is reported in Miller units.

\section{Results and Discussion}

\section{The N-terminal GAF domain of NifA regulates the activity of the catalytic domains}

Previous results have shown that the NifA protein from $A$. brasilense requires co-expression of the cognate GInB protein to activate nif gene expression in an $E$. coli background (8). In its native background, the NifA activity is regulated by the prevailing ammonium levels and the $\mathrm{N}$-terminal GAF domain of NifA has been implicated in ammonium-dependent regulation through interaction with the $\mathrm{GInB}$ protein $(5,7)$. To test the ability of the $A$. brasilense $\mathrm{N}$-truncated NifA protein to activate the transcription of nif genes in a heterologous background, we used the $E$. coli strains YMC10 (wild-type), RB9060 ( $\left.g \ln B^{-}\right)$, WCH30 ( $\left.g \ln K^{-}\right)$ and UNF3435 ( $g / n B^{-}$and $g / n K^{-}$) carrying a K. pneumoniae nifH'-lacZ chromosomal fusion (15) and plasmid pCNK5CCT, which expresses an $\mathrm{N}$-truncated form of $A$. brasilense NifA. The $E$. coli strains expressing the $\mathrm{N}$-truncated NifA protein showed 5-8 times higher $\beta$-galactosidase activity in cells assayed in the absence of oxygen, confirming that this variant of the NifA protein is active and reinforcing the evidence that the oxygen sensitivity of NifA is not related to the $\mathrm{N}$ terminal domain (Figure 1). Also, the activity was similar in cells assayed in the presence or absence of ammonium, confirming that removal of the N-terminus of NifA leads to loss of ammonium regulation. Nishikawa et al. (11) have reported similar results. In addition, we observed that the $\mathrm{N}$-truncated NifA was active and non-regulated regardless of the presence of genes encoding endogenous $P_{\text {II }}$ proteins 
( $g \ln K$ or $g \ln B$ ) in the $E$. coli backgrounds, although the $\beta$-galactosidase activity was approximately 2 -fold higher in strains RB9060 ( $g \ln B$ ) and UNF3435 ( $g / n B / g / n K)$ (Figure 1). We also determined the effect of in trans expression of the A. brasilense NifA N-terminal domain on the activity of the $\mathrm{N}$-truncated NifA protein in the same $E$. coli strains (Figure 1). The expression of these NifA variants under all conditions reported in Figure 1 was confirmed by immunoblot analysis (data not shown). The co-expression of a Histagged variant of the N-terminal GAF domain (NifANT-His) and the $\mathrm{N}$-truncated NifA caused a substantial decrease in $\beta$-galactosidase activity in all strains under low ammonium and anaerobiosis conditions, confirming the inhibitory role of the NifA N-terminal GAF domain. The expression of the GAF domain led to partial recovery of ammonium-dependent regulation of the $\mathrm{N}$-truncated NifA activity in the wild-type and glnK strains (YMC10 and WCH30, respectively) (Figure $1)$. In contrast, no regulation was observed in the strains lacking $g \ln B$ (RB9060 and UNF3435, respectively). These results indicate that the NifA GAF domain can inhibit in trans the N-truncated NifA protein and that regulation by ammonium requires the $E$. coli GInB but not GInK (Figure 1). The effects observed were not due to lack of expression of the NifA protein variants in the $E$. colistrains, since immunoblot assays with antibodies raised against the $\mathrm{N}$-truncated NifA and the $\mathrm{N}$-terminal domain revealed expression of both proteins under the $\beta$-galactosidase assay conditions (data not shown). It has been reported that the $E$. coli GInB but not $\mathrm{GInK}$ is able to activate the native $A$. brasilense NifA in an $E$. coli background, supporting evidence that $G \operatorname{lnB}$, but not GInK, plays a role in NifA regulation (6).

\section{The N-terminal GAF domain of NifA interacts with the GInB protein}

To determine if the NifA GAF domain interacts with the $\mathrm{P}_{\|}$proteins in vitro, pull-down assays were performed us-

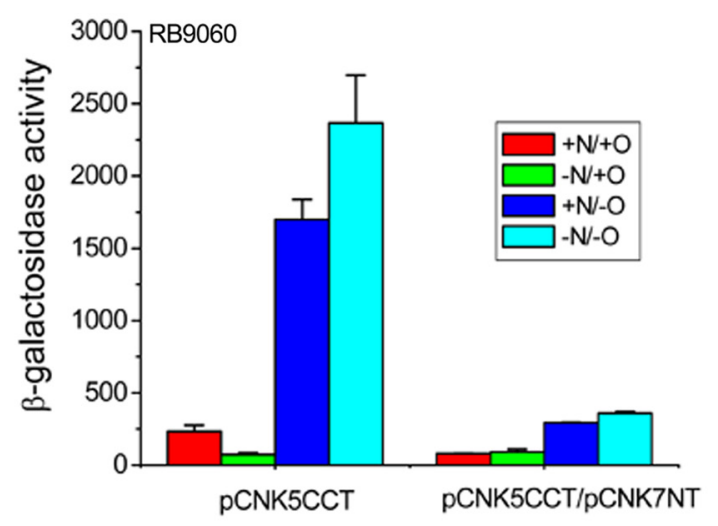

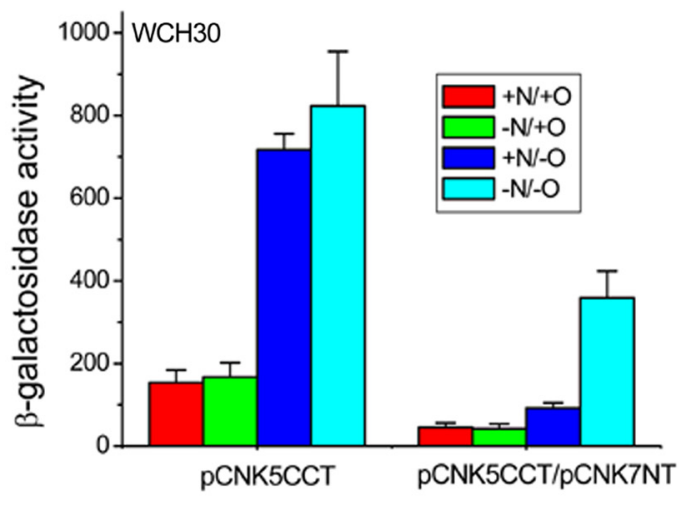
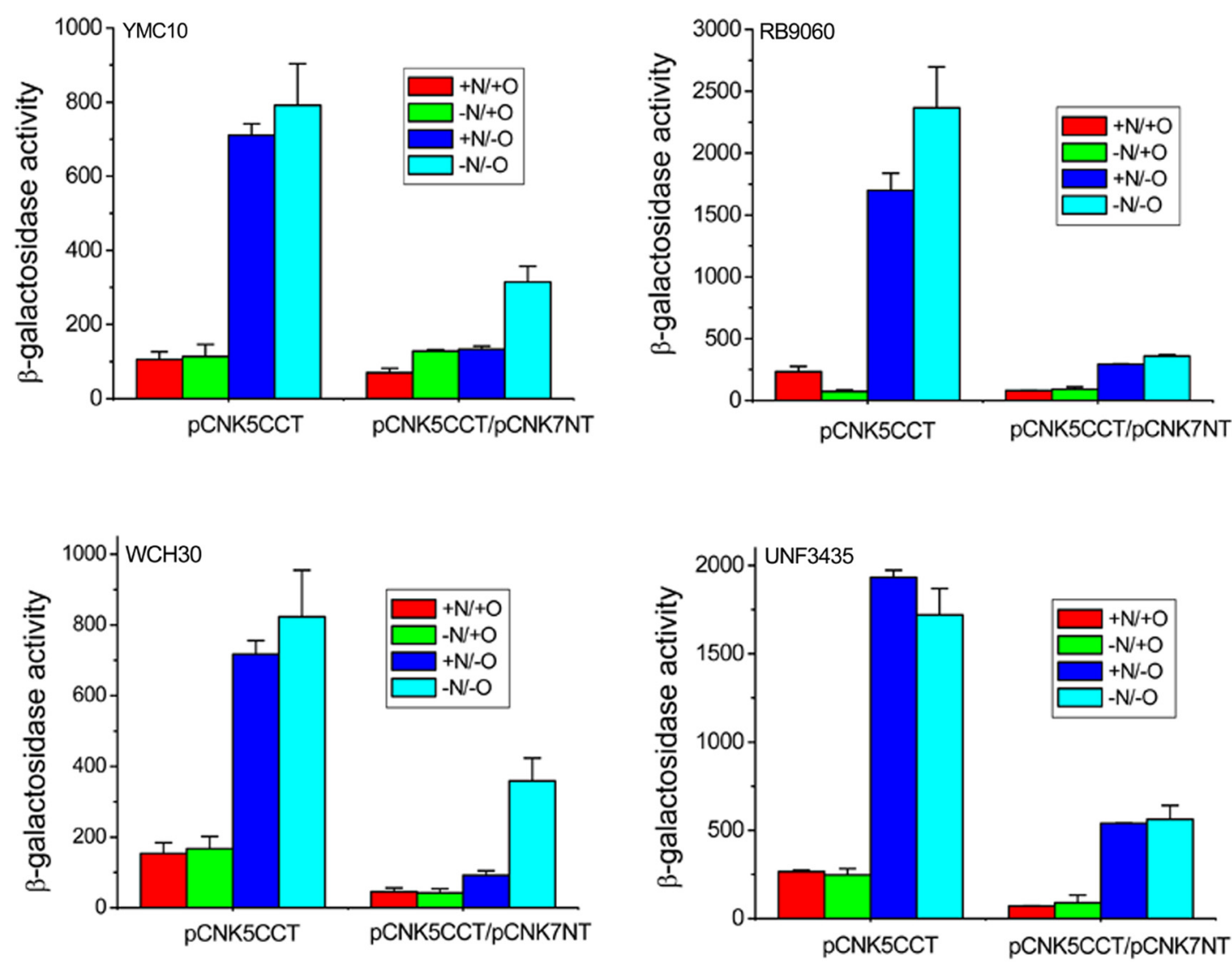

Figure 1. Transcriptional activation of Klebsiella pneumoniae nifH'-lacZ by Azospirillum brasilense N-truncated NifA in the presence or absence of the NifA N-terminal GAF domain. Assays were carried out in Escherichia coli strains YMC10 (wild type), RB9060 $\left(g / n B^{-}\right), W C H 30\left(g / n K^{-}\right)$, and UNF3435 $\left(g / n B^{-} / g / n K^{-}\right)$transformed by pCNK5CCT (N-truncated NifA domain) and/or pCNK7NT (NifA N-terminal GAF domain). Samples were incubated under air $(+O)$ or under $\mathrm{N}_{2}(-\mathrm{O})$, and in the presence $(+\mathrm{N})$ or absence $(-\mathrm{N})$ of $20 \mathrm{mM} \mathrm{NH}_{4} \mathrm{Cl}$ as described in Material and Methods. $\beta$-galactosidase activity is indicated in Miller units. Cells carrying no plasmid or only the pCNK7NT plasmid showed background activity of less than 150 Miller units. Data are the average of at least three independent experiments. 
ing NifANT-His as bait and the $A$. brasilense GInB or GInZ proteins. The NifANT-His protein bound to MagneHis-Ni ${ }^{2+}$ beads was incubated with $A$. brasilense $\mathrm{G} \ln \mathrm{B}$ or $\mathrm{G} \ln Z$ proteins. After extensive washing with binding buffer, the proteins bound to the MagneHis- $\mathrm{Ni}^{2+}$ were eluted with imidazole and analyzed by SDS-PAGE (Figure 2). GInB coprecipitated with NifANT-His only in the presence of MgATP and 2-oxoglutarate (Figure 2A), while GInZ did not interact with NifANT-His under any tested conditions (Figure 2B), confirming our previous hypothesis that $\mathrm{G} \ln B$ but not $\mathrm{G} \ln Z$ is involved in NifA regulation (6). Bovine serum albumin, used as a negative control, failed to bind to the MagneHis-Ni ${ }^{2+}$ beads charged with NifANT-His (data not shown).

Chen et al. (7) have previously shown that the A. brasilense NifA GAF domain could interact with GInB using yeast two-hybrid studies. Our in vitro analysis confirmed this observation and extended it by showing that this interaction requires the $G \ln B$ effectors MgATP and 2-oxoglutarate (Figure 2). The interaction between the NifA N-terminal GAF domain of $H$. seropedicae and the GInK protein is also stabilized by MgATP and 2-oxoglutarate in vitro (18).

The effectors MgATP and 2-oxoglutarate bind synergistically to nearly all $P_{\text {II }}$ proteins studied to date. The biochemical basis for such synergy is explained by the fact that the 2-oxoglutarate binding sites are located in the vicinity of the MgATP binding

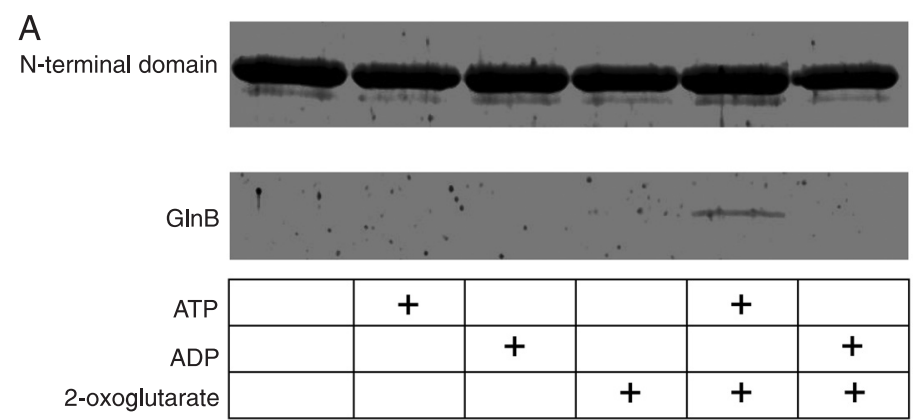

B $\mathrm{N}$-terminal domain
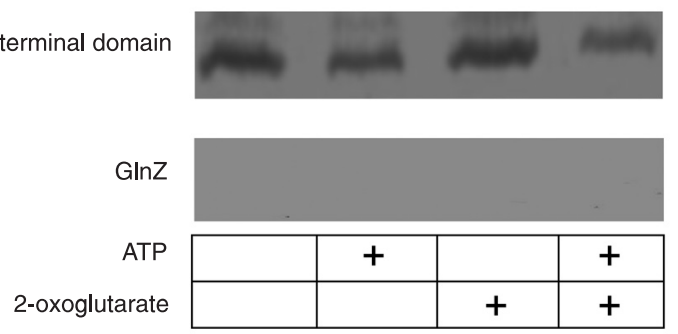

Figure 2. Pull-down assays of GInB bound to the NifA N-terminal domain on MagneHis-Ni ${ }^{2+}$ particles. The assays were carried out as described in Material and Methods. The NifA N-terminal-His domain $(0.25 \mu \mathrm{M})$ was immobilized on MagneHis-Ni ${ }^{2+}$ particles and incubated with $0.8 \mu \mathrm{M} \mathrm{G} \operatorname{lnB}$ (Panel A) or GInZ proteins (Panel B) in the presence of ATP or ADP (3.5 $\mathrm{mM})$ and/or 2-oxoglutarate $(2 \mathrm{mM})$ when indicated. Samples were run on $12.5 \%$ SDS-PAGE. The gels were stained with SYPRO Ruby. sites for 2-oxoglutarate (reviewed in Ref. 9). Based on the data reported in Figure 2, the $A$. brasilense GInB structure would only be able to interact with NifA when the GlnB trimmer is saturated with MgATP plus 2-oxoglutarate. However, we cannot exclude the possibility that 2-oxoglutarate also binds to the $A$. brasilense NifA GAF domain since the GAF domain of NifA from $A$. vinelandii interacts with this metabolite in vitro (19).

Our results show for the first time a direct in vitro interaction between the $\mathrm{N}$-terminal domain of NifA of $A$. brasilense and the signaling protein $G \ln B$, but not with $G \ln Z$, in the presence of MgATP and 2-oxoglutarate. The physiological significance for the requirement of MgATP and 2-oxoglutarate to promote the interaction between the NifA GAF domain and GInB is not yet clear. The 2-oxoglutarate pool fluctuates in vivo in response to nitrogen levels, increasing under nitrogen limitation and decreasing when nitrogen is

\section{References}

1. Dobereiner J, Pedrosa FO. Nitrogen-fixing bacteria in nonleguminous crop plants. New York: Springer-Verlag; 1987. abundant (20). Hence, GInB saturated with MgATP and 2-oxoglutarate should accumulate under nitrogen limitation (20). Nitrogen limitation also induces GInB uridylylation $(10,13)$. Although evidence suggests that $G \ln B$ uridylylation is required to relieve the inhibitory effect of the NifA GAF, the NifA-GInB interaction might be primarily modulated by the effectors bound to GInB rather than by the GInB uridylylation status. We are currently investigating the interaction of uridylylated GInB with NifA in vitro.

\section{Acknowledgments}

We are grateful to Roseli Prado, Valter Baura, Julieta Pie, and Marilza Lamour for technical assistance. We are also grateful to Dr. M. Geoffrey Yates (UK) for reading the manuscript. Research supported by INCT-Fixação Biológica de Nitrogênio, CNPq, CAPES, and Institutos do Milênio. 
3. Liang YY, Kaminski PA, Elmerich C. Identification of a nifA-like regulatory gene of Azospirillum brasilense Sp7 expressed under conditions of nitrogen fixation and in the presence of air and ammonia. Mol Microbiol 1991; 5: 27352744.

4. Souza EM, Pedrosa FO, Drummond M, Rigo LU, Yates MG. Control of Herbaspirillum seropedicae NifA activity by ammonium ions and oxygen. J Bacteriol 1999; 181: 681-684.

5. Arsene F, Kaminski PA, Elmerich C. Modulation of NifA activity by PII in Azospirillum brasilense: evidence for a regulatory role of the NifA N-terminal domain. J Bacteriol 1996; 178: 4830-4838.

6. Araujo LM, Monteiro RA, Souza EM, Steffens MB, Rigo LU, Pedrosa FO, et al. GInB is specifically required for AzospirilIum brasilense NifA activity in Escherichia coli. Res Microbiol 2004; 155: 491-495.

7. Chen S, Liu L, Zhou X, Elmerich C, Li JL. Functional analysis of the GAF domain of NifA in Azospirillum brasilense: effects of $\mathrm{Tyr} \rightarrow$ Phe mutations on NifA and its interaction with GlnB. Mol Genet Genomics 2005; 273: 415-422.

8. Zhou XY, Zou XX, Li JL. Interaction between GInB and the Nterminal domain of NifA in Azospirillum brasilense. Chinese Sci Bull 2008; 53: 3546-3552.

9. Huergo LF, Pedrosa FO, Muller-Santos M, Chubatsu LS, Monteiro RA, Merrick M, et al. PII signal transduction proteins: pivotal players in post-translational control of nitrogenase activity. Microbiology 2012; 158: 176-190.

10. de Zamaroczy M. Structural homologues $P(I I)$ and $P(Z)$ of Azospirillum brasilense provide intracellular signalling for selective regulation of various nitrogen-dependent functions. Mol Microbiol 1998; 29: 449-463.

11. Nishikawa CY, Araujo LM, Kadowaki MA, Monteiro RA, Steffens MB, Pedrosa FO, et al. Expression and characterization of an N-truncated form of the NifA protein of Azospirillum brasilense. Braz J Med Biol Res 2012; 45: 113-117.

12. Kleiner D, Paul W, Merrick MJ. Construction of multicopy expression vectors for regulated over-production of proteins in Klebsiella pneumoniae and other enteric bacteria. J Gen Microbiol 1988; 134: 1779-1784.

13. Araújo LM, Huergo LF, Invitti AL, Gimenes CI, Bonatto AC, Monteiro RA, et al. Different responses of the $\mathrm{G} \ln B$ and GInZ proteins upon in vitro uridylylation by the Azospirillum brasilense GInD protein. Braz J Med Biol Res 2008; 41: 289294.

14. Moure VR, Razzera G, Araujo LM, Oliveira MA, Gerhardt EC, Muller-Santos M, et al. Heat stability of Proteobacterial PII protein facilitate purification using a single chromatography step. Protein Expr Purif 2012; 81: 83-88.

15. Arcondeguy T, van Heeswijk WC, Merrick M. Studies on the roles of GInK and GInB in regulating Klebsiella pneumoniae NifL-dependent nitrogen control. FEMS Microbiol Lett 1999; 180: $263-270$.

16. Cannon FC, Dixon RA, Postgate JR, Primrose SB. Chromosomal integration of Klebsiella nitrogen fixation genes in Escherichia coli. J Gen Microbiol 1974; 80: 227-239.

17. Miller JH. Experiments in molecular genetics. Cold Spring Harbor: Cold Spring Harbor Laboratory Press; 1972.

18. Oliveira MA, Aquino B, Bonatto AC, Huergo LF, Chubatsu LS, Pedrosa FO, et al. Interaction of GInK with the GAF domain of Herbaspirillum seropedicae NifA mediates $\mathrm{NH}(4)$ (+)-regulation. Biochimie 2012; 94: 1041-1047.

19. Little R, Dixon R. The amino-terminal GAF domain of Azotobacter vinelandii NifA binds 2-oxoglutarate to resist inhibition by NifL under nitrogen-limiting conditions. J Biol Chem 2003; 278: 28711-28718.

20. Radchenko MV, Thornton J, Merrick M. Control of AmtBGInK complex formation by intracellular levels of ATP, ADP, and 2-oxoglutarate. J Biol Chem 2010; 285: 31037-31045. 